\title{
Once, I Lived in a House with a Name
}

\author{
Mohamed Assaf and Kate Clanchy
}

ABSTRACT: Five poems written by Mohamed Assaf (a young Syrian boy who currently lives in Oxford with his family and studies at Oxford Spires Academy) under the mentorship of the poet Kate Clanchy. The introduction and poems themselves offer a reflection on Mohamed's old and new place(s) in the world, and the significance of writing as a way of responding to, and resisting, "refugeedom."

KEYWORDS: childhood, home, loss, poetry, refugee, school

These poems were not, as their elegiac, melancholic tone seems to imply, written by a 60-something exile remembering his childhood, but by a small Syrian boy with a grubby collar and a large football, named Mohamed Assaf. He is not an easy child: he does poetry with me every week, partly in the hope of improving his behavior. So these poems are also not composed in an elegant study, but at the backs of crowded classrooms. The central three poems in this sequence were scribbled on a piece of lined A4 in 20 minutes as Mohamed listened to Azfa Awad, a Somali poet, give a workshop in Swahili, seemingly stimulated by the rhythms of her speech and by her own refugee poems written on the board in English.

Nor has my translation process been elegant. Mohamed types his poems into Google translate and extraordinary suggestions - "national incubator," "brotherhood of foreignness"-turn up on the tiny screen. I write bits down, I gesture, we enlist the help of passing academics when we can and other Arabic-speaking children in the school when we cannot. I explain to Mohamed that English is poor, and that to address the gaps in the rhymes and half-rhymes, I have to use repetition and play with stanza breaks. Mostly he seems to understand. Sometimes he takes a break and stands on his football for a while.

I get tired too, but mostly I am thrilled because Mohamed seems to me a poet in that his images and thoughts coincide and circle on each other. The poem about raising his hand to answer the question and to spell the name of his country, for example-one of the poems we translated by gesture, pushing our hands up in the air and across the paper as well as on paperis a poem because of those overlapping images of hands. I used "gloved" in English after putting on a glove to check that was right.

Only a child raises their hand to answer a question, and it is the combination of the child and the grand Arabic voice that has made Mohamed a "Twitter star." His tiny poem "I have divided my heart" was retweeted more than three thousand times, including by Muslim footballers, French Algerian beauticians, and British poets, among others. It is not just his "cute" photo: it is because inside the elegant Arabic shadows and flowers we see a small child turning the globe and wondering what has been done to him. 


\section{Five Poems by Mohamed Assaf}

\section{When my teacher asked me}

what I was going to be

I did not think of "refugee."

But the child who saw a war,

who left his country

to strangers: that's me.

Refugee. Refugee.

The word the West

Was holding for me.

\section{Definitions}

When they asked me about love,

I said, Damascus.

A land like Damascus,

Damascus in the warm light of my memory

The neighborhood that loved me

The homeland that felt right

to the right people with the right people in it.

When they asked me about hate

I said, the politicians.

I said, they are the lowest.

Take their homeland away.

\section{Sham}

When I was in Syria

I did not count up

how lucky I was

when I raised my hand

to spell the word "happiness";

when I got each letter correct.

Now my hand is gloved

in strangeness. Now,

I try to write the name

of my country from

the wrong margin.

Four letters. Each letter hurts. 


\section{So said the child refugee}

"I have a pain which is here all the time

A pain it is hard to explain:

the strangeness in every letter of exile;

this burning at my heart.

Me and my brothers in foreignness-

We grew and were loved in a land

which is not there now. Now, we are

always foreign, exiles inside our lives."

\section{Where are my unnumbered days?}

Once I lived in a beautiful town;

Once, I owned a beautiful house,

with a grand garden full of flowers,

and I was prince of it all. Once,

I lived in a house with a name:

And now, I am just a number.

Nations talked to nations

And robbed me of myself.

They made me

a number among millions.

But my rights have no number.

My home had no number.

I could not count the petals of the flowers

My childhood in the garden

had no limits on it.

Take me back to my country

And I can show you the numbers.

The numbers who suffer;

the quantities of beauty;

the fallen flowers.

MOHAMED ASSAF is a young Syrian boy who currently lives in Oxford with his family; he studies at Oxford Spires Academy.

KATE CLANCHY is a poet and teacher who works closely with young people, including refugees and migrants, at Oxford Spires Academy. She is the editor of the 2018 collection England: Poems from a School (Picador, May 2018). 